\title{
PEMILIHAN KONTRAKTOR JASA SEWA PEMBANGKIT PASCA MVPP BEROPERASI DI SISTEM PEMBANGKIT DENGAN MENGGUNAKAN METODE AHP (STUDY KASUS PADA PLN AREA AMBON)
}

\author{
V. O. Lawalata \\ Dosen Program Studi Teknik Industri, Fakultas Teknik Universitas Pattimura, Ambon \\ Angga Almada \\ Program Studi Teknik Industri, Fakultas Teknik Universitas Pattimura, Ambon
}

\begin{abstract}
ABSTRAK
Marine Vessel Power Plan (MVPP) adalah Pembangkit Sewa diesel yang terletak di Kapal Laut, yang dioperasikan dengan batas aman beban kontinyu 48 MW. Beban sistem Ambon diperkirakan mencapai 56 MW pada akhir tahun 2017, sehingga diperlukan pembangkit lain untuk membantu memenuhi beban listrik itu. Penlitian skripsi ini dilakukan untuk memilih kontraktor jasa sewa pembangkit tambahan yang tepat untuk mendukung pemenuhan permintaan beban listrik sistem Ambon berdasarkan aspek teknis (konsumsi bahan bakar, waktu penyediaan daya kontrak), sosial dan lingkungan (emisi gas buang, tingkat kebisingan), serta biaya yang menguntungkan PLN Area Ambon (biaya pokok produksi, biaya sewa). Setelah dianalisis menggunakan metode Analytical Hierarchy Process (AHP), hasil penelitian menyatakan Sewatama sebagai pembangkit yang paling tepat bagi sistem ambon dibandingkan Sewa Wesa, Sewa PYM dan Sewa CPI

Kata kunci : Pemilihan Jasa Kontraktor Sewa Pembangkit Tambahan, Analytical Hierarchy Process
\end{abstract}

\begin{abstract}
Marine Power Vessel Power Plan (MVPP) is a diesel rental generator provided on ships, which is operated with a safe limit of $48 \mathrm{MW}$ continuous loads. Since the Ambon system load is estimated to reach $56 \mathrm{MW}$ at the end of 2017, other plants are needed to help meet the electricity load. This research is carried out to select the appropriate rental service contractor to support the fulfillment of the Ambon electricity system demand. Assessments are based on technical aspects (fuel consumption, time for contracting), social and environment (gas emissions, performance, and costs that benefit the PLN Area Ambon (the cost of production, rent). By using Analytical Hierarchy Process (AHP) method, the results of research stated that Sewatama was the most appropriate generator for the Ambon system compared to Wesa Rental, PYM Rental, and CPI Rental..
\end{abstract}

Keywords: Selection of Additional Generator Rental Contractor Services, Analytical Hierarchy Process

\section{PENDAHULUAN}

Pembangkit Listrik Tenaga Diesel (PLTD) adalah pembangkit listrik yang menggunakan mesin diesel berbahan bakar High Speed Diesel (HSD) atau solar sebagai penggerak mula (prime mover). Prime mover merupakan peralatan yang berfungsi menghasilkan energi mekanis untuk memutar rotor generator sehingga energi listrik dapat diproduksi. Keuntungan utama penggunaan pembangkit listrik tenaga diesel adalah praktis untuk dibangun pada kondisi geografis kepulauan seperti Maluku dan dapat beroperasi sepanjang waktu selama masih tersedianya bahan bakar. PLTD biasanya digunakan untuk memenuhi kebutuhan listrik dalam jumlah beban kecil, terutama untuk daerah baru yang terpencil atau untuk listrik pedesaan dan untuk memasok kebutuhan listrik suatu pabrik.

Keandalan pembangkit ini tinggi karena dalam operasinya tidak bergantung pada alam seperti halnya PLTA. Mengingat waktu startnya yang cepat namun ongkos bahan bakarnya tergolong mahal dan bergantung dengan perubahan harga minyak dunia yang cenderung meningkat dari tahun ke tahun, PLTD disarankan hanya dipakai untuk melayani konsumen pada saat beban puncak.

Marine Vessel Power Plan (MVPP) adalah Pembangkit Sewa diesel yang terletak di Kapal Laut, direncanakan akan berlabuh di wai pada Maret - April 2017 dengan kapasitas Sewa 60 MW. Dengan 
beroperasinya MVPP maka komposisi pembangkit sistem Ambon berubah. Pembangkit sewa eksisting dengan total daya kontrak $50 \mathrm{MW}$ akan diputus kontrak sehingga memerlukan pembangkit sewa lain.

MVPP akan dioperasikan dengan batas aman beban kontinyu 48 MW meskipun luas penampang saluran transmisi adalah ACSR $240 \mathrm{~mm}$ dengan KHA $60 \mathrm{MW}$. Dengan keterbatasan ini masih diperlukan pembangkit lain untuk membantu memikul beban sistem Ambon yang diperkirakan mencapai 56 MW pada akhir tahun 2017.

Tujuan dari penelitian ini adalah untuk membantu melakukan pemilihan komposisi pembangkit sewa tambahan yang tepat berdasarkan kriteria Aspek Teknis, Aspek Lingkungan dan Sosial dan Aspek Biaya yang menguntungkan perusahaan.

\section{LANDASAN TEORI.}

\section{Analytic Hierarchy Process}

Metode Analytic Hierarchy Process (AHP) merupakan teori umum mengenai pengukuran. Empat macam skala pengukuran yang biasanya digunakan secara berurutan adalah skala nominal, ordinal, interval dan rasio. Skala yang lebih tinggi dapat dikategorikan menjadi skala yang lebih rendah, namun tidak sebaliknya. Pendapatan per bulan yang berskala rasio dapat dikategorikan menjadi tingkat pendapatan yang berskala ordinal atau kategori (tinggi, menengah, rendah) yang berskala nominal. Sebaliknya jika pada saat dilakukan pengukuran data yang diperoleh adalah kategori atau ordinal, data yang berskala lebih tinggi tidak dapat diperoleh. AHP mengatasi sebagian permasalahan itu. (Saaty,2001) AHP digunakan untuk menurunkan skala rasio dari beberapa perbandingan berpasangan yang bersifat diskrit maupun kontinu. Perbandingan berpasangan tersebut dapat diperoleh melalui pengukuran aktual maupun pengukuran relatif dari derajat kesukaan, atau kepentingan atau perasaan. Dengan demikian metode ini sangat berguna untuk membantu mendapatkan skala rasio dari hal-hal yang semula sulit diukur seperti pendapat, perasaan, prilaku dan kepercayaan. (Saaty,2001) Penggunaan AHP dimulai dengan membuat struktur hirarki atau jaringan dari permasalahan yang ingin diteliti. Di dalam hirarki terdapat tujuan utama, kriteriakriteria, sub kriteria-sub kriteria dan alternatif-alternatif yang akan dibahas.

Perbandingan berpasangan dipergunakan untuk membentuk hubungan di dalam struktur. Hasil dari perbandingan berpasangan ini akan membentuk matrik dimana skala rasio diturunkan dalam bentuk eigen vektor utama atau fungsi-eigen. Matrik tersebut berciri positif dan berbalikan, yakni aij $=1 /$ aji. (Saaty,2001) Sebagai studi kasus, dilakukan pengumpulan data tentang nilai kepentingan faktor-faktor yang berpengaruh dalam hal melakukan perjalanan menuju tempat kuliah. Data tersebut berupa data perbandingan berpasangan dengan skala 1-9. Data yang terkumpul tersebut diolah dengan metode AHP yang sebelumnya dilakukan perhitungan geometrik rerata untuk mendapatkan matriks perbandingan berpasangan, kemudian diuji nilai consistency ratio (CR)-nya yaitu data yang CR-nya kurang dari $10 \%$ yang dianggap konsisiten. Untuk mendapatkan hasil yang diharapkan, dilakukan analisa sensitivitas terhadap prioritas pemilihan alternatif moda yang ada. Analisa ini dilakukan dengan cara trial dan error pada masing-masing faktor. Dengan cara ini dapat dilihat kecenderungannya sehingga dapat diketahui pengaruhnya terhadap pergeseran prioritas pemilihan alternatif moda. Penelitian mengenai "Faktor-Faktor yang Mempengaruhi Pemilihan Moda Transportasi untuk Perjalanan Kuliah" dengan menggunakan metode Analytic Hierarchy Process" ini, dilakukan hanya pada mahasiswa/i kampus Unpatti . Data primer seperti kriteria-kriteria pemilihan moda transportasi (aman, nyaman, biaya, waktu), data responden, diperoleh melalui pengisian kuisioner, wawancara dan observasi di lokasi penelitian. Data sekunder yang penulis kumpulkan berupa data jumlah mahasiswa/i kampus Unpatti.

Analytic Hierarchy Process (AHP) mempunyai landasan aksiomatik yang terdiri dari :

1. Resiprocal Comparison, yang mengandung arti bahwa matriks perbandingan berpasangan yang terbentuk harus bersifat berkebalikan. Misalnya, jika A adalah $\mathrm{f}$ kali lebih penting dari pada B maka $\mathrm{B}$ adalah1/f kali lebih penting dari A.

2. Homogenity, yaitu mengandung arti kesamaan dalam melakukan perbandingan. Misalnya, tidak dimungkinkan membandingkan jeruk dengan bola tenis dalam hal rasa, akan tetapi lebih relevan jika membandingkan dalam hal berat.

3. Dependence, yang berarti setiap level mempunyai kaitan (complete hierarchy) walaupun mungkin saja terjadi hubungan yang tidak sempurna (incomplete hierarchy).

4. Expectation, yang berarti menonjolkon penilaian yang bersifat ekspektasi dan preferensi dalam pengambilan keputusan. Penilaian dapat merupakan data kuantitatif maupun yang bersifat kualitatif.

Tahapan - tahapan pengambilan keputusan dalam metode AHP pada dasarnya adalah sebagai berikut :

1. Mendefinisikan masalah dan menentukan solusi yang diinginkan

2. Membuat struktur hirarki yang diawali dengan tujuan umum, dilanjutkan dengan kriteria-kriteria dan alternaif-alternatif pilihan yang ingin dirangking. 
3. Membentuk matriks perbandingan berpasangan yang menggambarkan kontribusi relatif atau pengaruh setiap elemen terhadap masing-masing tujuan atau kriteria yang setingkat diatasnya. Perbandingan dilakukan berdasarkan pilihan atau judgement dari pembuat keputusan dengan menilai tingkat tingkat kepentingan suatu elemen dibandingkan elemen lainnya

4. Menormalkan data yaitu dengan membagi nilai dari setiap elemen di dalam matriks yang berpasangan dengan nilai total dari setiap kolom.

5. Menghitung nilai eigen vector dan menguji konsistensinya, jika tidak konsisten maka pengambilan data (preferensi) perlu diulangi. Nilai eigen vector yang dimaksud adalah nilai eigen vector maximum yang diperoleh dengan menggunakan matlab maupun dengan manual.

6. Mengulangi langkah 3, 4, dan 5 untuk seluruh tingkat hirarki.

7. Menghitung eigen vector dari setiap matriks perbandingan berpasangan. Nilai eigen vector merupakan bobot setiap elemen. Langkah ini untuk mensintesis pilihan dalam penentuan prioritas elemen-elemen pada tingkat hirarki terendah sampai pencapaian tujuan.

8. Menguji konsistensi hirarki. Jika tidak memenuhi dengan $\mathrm{CR}<0,100$ maka penilaian harus diulang kembali.

\section{Prinsip Dasar Analytic Hierarchy Process (AHP)}

Dalam menyelesaikan persoalan dengan metode AHP ada beberapa prinsip dasar yang harusdipahami antara lain:

1. Decomposition

Decomposition adalah memecahkan atau membagi problema yang utuh menjadi unsur — unsurnya ke bentuk hirarki proses pengambilan keputusan, dimana setiap unsur atau elemen saling berhubungan. Struktur hirarki keputusan tersebut dapat dikategorikan sebagai complete dan incomplete. Suatu hirarki keputusan disebut complete jika semua elemen pada suatu tingkat memiliki hubungan terhadap semua elemen yang ada pada tingkat berikutnya, sementara hirarki keputusan incomplete kebalikan dari hirarki yang complete. Bentuk struktur dekomposisi yakni

$>\quad$ Tingkat pertama :Tujuan keputusan(Goal)

$>$ Tingkatakedua :Kriteria—kriteria

$>$ Tingkat ketiga :Alternatif_alternative

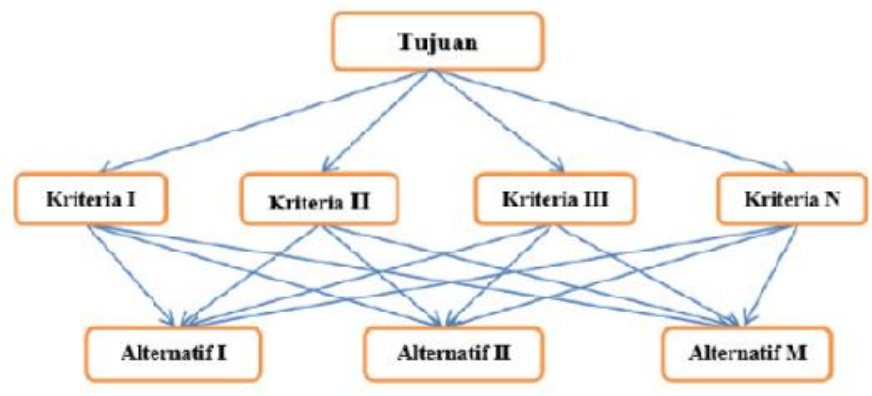

\section{Hierarki Masalah Dalam AHP}

Hirarki masalah disusun digunakan untuk membantu proses pengambilan keputusan dalam sebuah sistem dengan memperhatikan seluruh elemen keputusan yang terlibat.

2. Comparative Judgement

Comparative Judgement adalah penilaian yang dilakukan berdasarkan kepentingan relatif dua elemen pada suatu tingkat tertentu dalam kaitannya dengan tingkatan di atasnya. Comparative Judgement merupakan inti dari penggunaan AHP karena akan berpengaruh terhadap urutan prioritas dari elemen elemennya. Hasil dari penilaian tersebut akan diperlihatkan dalam bentuk matriks pairwise comparisons yaitu matriks perbandingan berpasangan memuat tingkat preferensi beberapa alternatif untuk tiap kriteria. Skala preferensi yang digunakan yaitu skala 1 yang menunjukkkan tingkat yang paling rendah (equal importance) sampai dengan skala 9 yang menunjukkan tingkatan yang paling tinggi (extreme importance).

3. Synthesis of Priority

Synthesis of Priority dilakukan dengan menggunakan eigen vector method untuk mendapatkan bobot relatif bagi unsur-unsur pengambilan keputusan.

4. Logical Consistency 
Logical Consistency dilakukan dengan mengagresikan seluruh eigen vektor yang diperoleh dari berbagai tingkatan hirarki dan selanjutnya diperoleh suatu vektor composite tertimbang yang menghasilkan urutan pengambilan keputusan.

Keuntungan dari AHP sebagai berikut :

1. Unity: AHP menyediakan model tunggal, mudah dipahami, fleksibel untuk suatu cakupan luas tentang permasalahan tidak tersusun.

2. Complexity: AHP mengunakan pendekatan dedukatif dan sistem dalam memecahkan masalah yang rumit.

3. Interndependence: AHP dapat berhadapan dengan saling ketergantungan unsur-unsur di dalam suatu sistem dan tidak meminta dengan tegas atas pemikiran linier.

4. Hierarchi structuring: AHP mencerminkan kecenderungan alami dari pikiran ke unsur-unsur jenis dari sautu sistem ke dalam tingkat yang berbeda dan untuk mengolongkan seperti unsur-unsur pada setiap tingkatan.

5. Measurement: AHP menyediakan suatu skala untuk mengukur yang tak terukur dan suatu metoda untuk menetapkan prioritas.

6. Consistency: AHP taksiran pada konsistensi keputusan yang logis digunakan dalam hal yang menentukan.

7. Synthesis: AHP memimpin ke arah suatu keseluruhan perkiraan yang menyangkut suatu keinginan dari tiap alternatif.

8. Trade offs: AHP mempertimbangkan dengan seksama prioritas relatif faktor dalam suatu sistem dan memungkinkan orang untuk memilih alternatif yang terbaik yang berdasar atas tujuan.

9. Judgement and consensus: AHP tidak meminta dengan tegas atas konsensus tetapi menyatukan suatu hasil bagian dari keputusan berbeda.

10. Process repetition: AHP memungkinkan orang untuk memerinci definisi mereka dari suatu masalah dan untuk meningkatkan pemahaman dan pertimbangan mereka dengan melakukan pengulangan.

Sedangkan kelemahan metode AHP adalah sebagai berikut :

1. Ketergantungan model AHP pada input utamanya. Input utama ini berupa persepsi seorang ahli sehingga dalam hal ini melibatkan subjektifitas sang ahli selain itu juga model menjadi tidak berarti jika ahli tersebut memberikan penilaian yang keliru.

2. Metoda AHP ini hanya metoda matematis tanpa ada pengujian secara statistik sehingga tidak ada batas kepercayaan dari kebenaran model yang terbentuk

\section{METODE PENELITIAN}

\section{Variabel dan Definisi Operasional}

Variabel keputusan dapat dinotasikan dengan lambang X. Yang termasuk dalam indikator variabel keputusan dalam penilitian adalah sebagai berikut :

a. Tingkat Konsumsi Bahan Bakar (Liter) (X1)

b. Waktu Penyediaan Daya Kontrak (Hari) (X2)

c. Emisi gas buang (\%) (X3)

d. Tingkat Kebisingan (dB) (X4)

e. $\quad$ Biaya Pokok Produksi (Rp/kWh) (X5)

f. Harga Sewa (Rp/kWh) (X6)

Variabel keputusan merupakan suatu indikator untuk mencapai variabel tujuan. Yang mana variabel tujuan adalah Pemilihan Sewa Pembangkit Di Sistem Ambon (Unit)

\section{Metode Analisa Data}

Metode dalam penelitian ini menggunakan metode AHP (Analytical Hierarchy Process). Berikut ini merupakan flowchact dari penelitian ini. 


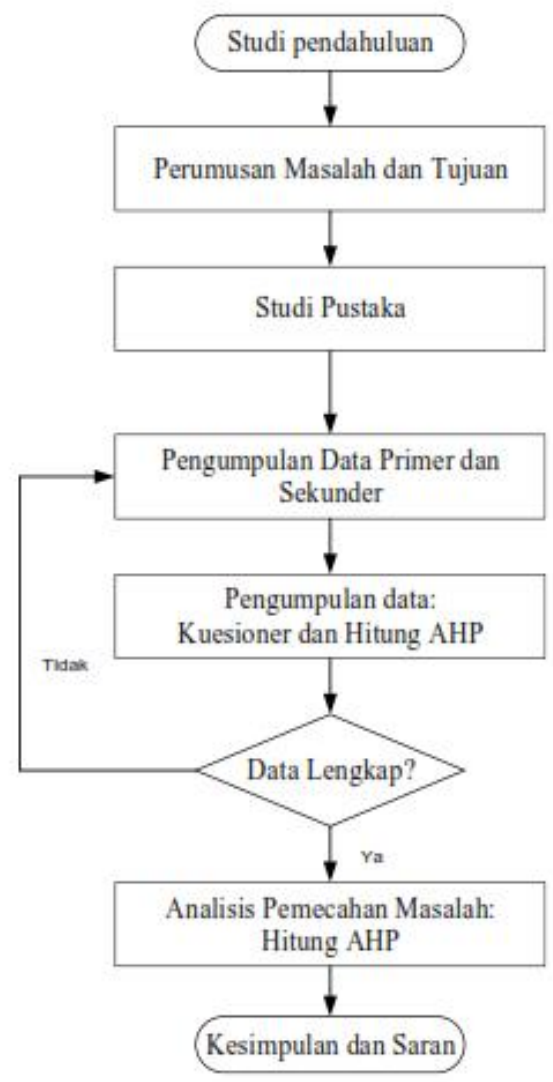

Flowchart Penelitian

Hasil Dan Pembahasan

Desain Model Pengambilan Keputusan

Hasil dan pembahasan Alternatif Pemilihan Kontraktor Jasa Sewa Pembangkit Pasca MVPP Beroperasi Di Sistem Pembangkit (di PLN Area Ambon) .

Penentuan jenis mesin sewa pembangkit di Sistem Ambon dilakukan menurut urutan yang ada dalam model Analitycal Hierarchy Process (AHP) yang dapat dijelaskan sebagai berikut :
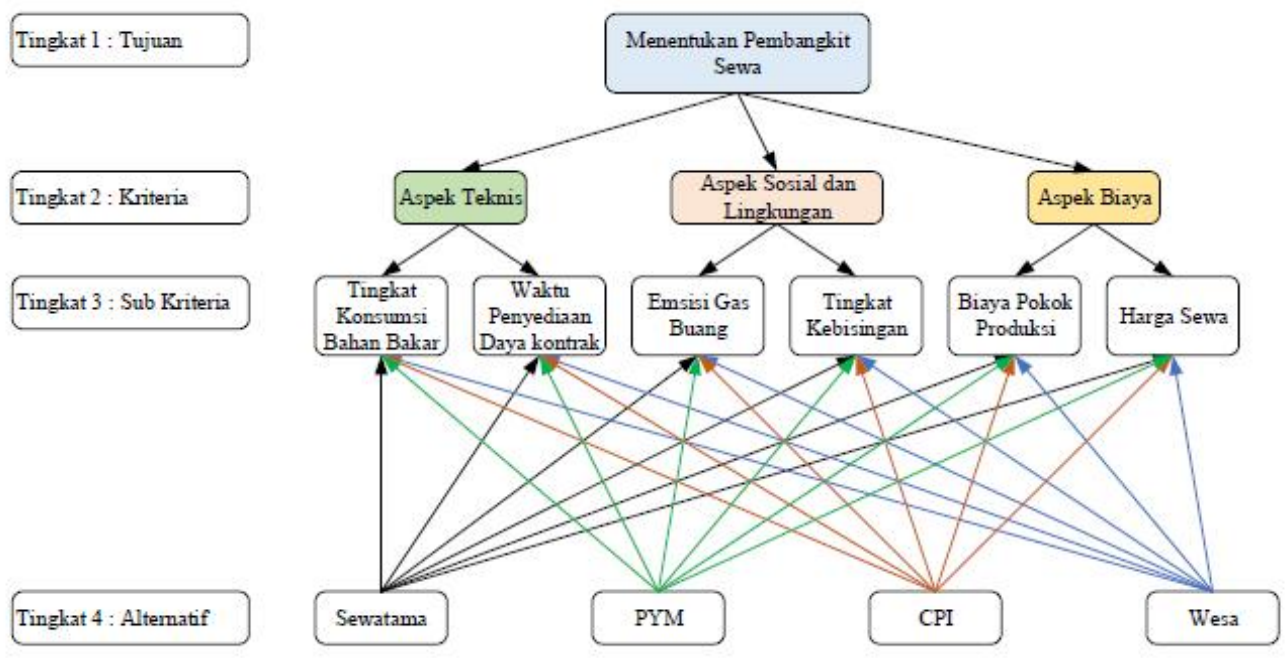

Desain Model 
- $\quad$ Tingkat 1 : Merupakan tujuan penelitian tugas akhir ini yaitu Menentukan Pembangkit Sewa di Sistem Ambon

- $\quad$ Tingkat 2 : Merupakan kriteria yang digunakan dalam pertimbangan penentuan jenis bahan bakar untuk mesin pembangkit dimana terdapat Aspek Teknis, Lingkungan dan Sosial, serta Aspek Biaya. Aspek Teknis adalah aspek yang menyangkut kesiapan perusahaan dalam membangun suatu proyek, dalam hal ini adalah pembangunan pembangkit baru. Parameter yang tergolong kedalam Aspek teknis seperti Tingkat konsumsi bahan bakar dan Waktu penyediaan kontrak. Aspek Lingkungan dan Sosial adalah aspek yang berkaitan dengan dampak yang dihasilkan dari suatu usaha/proyek terhadap kehidupan penduduk sekitar lokasi usaha serta akibat yang ditimbulkan dari usaha tersebut pada lingkungan. Aspek Biaya merupakan aspek yang berhubungan dengan masalah finansial, dalam hal usaha dikelompokkan menjadi biaya investasi dan biaya operasi. Biaya investasi ini merupakan seberapa besar dana yang dikeluarkan untuk membangun suatu usaha dan dalam jangka berapa lama modal tersebut bisa kembali. Biaya operasi yaitu biaya yang dikeluarkan untuk mendukung kegiatan operasional.

- $\quad$ Tingkat 3 : Merupakan Sub Kriteria yang digunakan dalam penilaian Alternatif penentuan jenis bahan bakar untuk mesin pembangkit (Aspek Teknis : Tingkat konsumsi bahan bakar dan Waktu penyediaan kontrak, Aspek Lingkungan dan Sosial : emisi gas buang dan tingkat kebisingan, Aspek Biaya : biaya produksi per kWh, dan biaya sewa.

- $\quad$ Tingkat 4 : Merupakan Alternatif penentuan untuk sewa mesin pembangkit.

\section{DATA KUISONER}

Data kuisioner didapatkan dari hasil wawancara yang dilakukan peneliti kepada Deputy Manajer Pembangkitan. Proses ini dilakukan untuk mendapatkan penilaian terhadap kriteria dan sub kriteria dari setiap alternatif pembangkit yang terkait dengan penelitian. Adapun data yang didapat dari quisioner tersebut sebagai berikut :

Perbandingan antar Kriteria

\begin{tabular}{|l|r|r|r|}
\hline \multicolumn{1}{|c|}{ Kriteria } & Aspek Teknis & Aspek Lingkungan & Aspek Biaya \\
\hline Aspek Teknis & 1,00 & 7,00 & 3,00 \\
\hline Aspek Lingkungan & 0,14 & 1,00 & 0,20 \\
\hline Aspek Biaya & 0,33 & 5,00 & 1,00 \\
\hline ¿ Kolom & 1,48 & 13,00 & 4,20 \\
\hline
\end{tabular}

Sumber Data : Kuisioner dengan DM Pembangkitan PLN MMU

Perbandingan antar Sub Kriteria pada Aspek Teknis

\begin{tabular}{|c|c|c|}
\hline Sub Kriteria & $\begin{array}{l}\text { Tingkat } \\
\text { Konsumsi } \\
\end{array}$ & $\begin{array}{l}\text { Waktu penyediaan } \\
\text { daya kontrak }\end{array}$ \\
\hline $\begin{array}{l}\text { Tingkat Konsumsi } \\
\text { Bahan Bakar }\end{array}$ & 1,00 & 5,00 \\
\hline $\begin{array}{l}\text { Waktu penyediaan } \\
\text { daya kontrak }\end{array}$ & 0,20 & 1,00 \\
\hline$\Sigma$ Kolom & 1,20 & 6,00 \\
\hline
\end{tabular}

Sumber Data : Kuisioner dengan DM Pembangkitan PLN MMU

Perbandingan antar Sub Kriteria pada Aspek Lingkungan

\begin{tabular}{|l|r|l|}
\hline \multicolumn{1}{|c|}{ Sub Kriteria } & $\begin{array}{l}\text { Emisi Gas } \\
\text { Buang }\end{array}$ & $\begin{array}{l}\text { Tingkat } \\
\text { Kebisingan }\end{array}$ \\
\hline $\begin{array}{l}\text { Emisi Gas } \\
\text { Buang }\end{array}$ & 1,00 & 2,00 \\
\hline $\begin{array}{l}\text { Tingkat } \\
\text { Kebisingan }\end{array}$ & 0,50 & 1,00 \\
\hline $\begin{array}{r}\text { E Kolom } \\
\hline\end{array}$ & 1,50 & 3,00 \\
\hline
\end{tabular}

Sumber Data : Kuisioner dengan DM Pembangkitan PLN MMU 
Perbandingan antar Sub Kriteria pada Aspek Biaya

\begin{tabular}{|l|r|r|}
\hline \multicolumn{1}{|c|}{ Sub Kriteria } & $\begin{array}{l}\text { Biaya Pokok } \\
\text { Produksi/KWH }\end{array}$ & Harga Sewa \\
\hline $\begin{array}{l}\text { Biaya Pokok } \\
\text { Produksi/KWH }\end{array}$ & 1,00 & 6,00 \\
\hline Harga Sewa & 0,17 & 1,00 \\
\hline$\Sigma$ Kolom & 1,17 & 7,00 \\
\hline
\end{tabular}

Sumber Data : Kuisioner dengan DM Pembangkitan PLN MMU

Perbandingan antar Alternatif Sub Kriteria Tingkat Konsumsi Bahan Bakar

Tingkat Konsumsi Bahan Bakar
\begin{tabular}{|l|r|r|r|r|}
\hline \multicolumn{1}{|c|}{ Kriteria } & Wesa & \multicolumn{1}{l|}{ CPI } & Sewatama & PYM \\
\hline Wesa & 1,00 & 1,17 & 0,89 & 1,19 \\
\hline CPI & 0,85 & 1,00 & 0,81 & 0,87 \\
\hline Sewatama & 1,12 & 1,24 & 1,00 & 1,20 \\
\hline PYM & 0,84 & 1,15 & 0,83 & 1,00 \\
\hline$\Sigma$ Kolom & 3,82 & 4,56 & 3,53 & 4,26 \\
\hline
\end{tabular}

Sumber Data : Kuisioner dengan DM Pembangkitan PLN MMU

Perbandingan antar Alternatif Sub Kriteria Waktu Penyediaan Kontrak

Waktu penyediaan daya kontrak
\begin{tabular}{|l|r|r|r|r|}
\hline \multicolumn{1}{|c|}{ Kriteria } & Wesa & \multicolumn{1}{l|}{ CPI } & Sewatama & PYM \\
\hline Wesa & 1,00 & 1,19 & 1,20 & 1,07 \\
\hline CPI & 0,84 & 1,00 & 1,00 & 1,02 \\
\hline Sewatama & 0,83 & 1,00 & 1,00 & 1,05 \\
\hline PYM & 0,93 & 0,98 & 0,95 & 1,00 \\
\hline$\Sigma$ Kolom & 3,61 & 4,17 & 4,15 & 4,14 \\
\hline
\end{tabular}

Sumber Data : Kuisioner dengan DM Pembangkitan PLN MMU

Perbandingan antar Alternatif Sub Kriteria Emisi Gas Buang

\begin{tabular}{|c|c|c|c|c|}
\hline \multicolumn{5}{|c|}{ Emisi Gas Buang } \\
\hline Kriteria & Wesa & CPI & Sewatama & PYM \\
\hline Wesa & 1,00 & 1,05 & 0,78 & 1,13 \\
\hline CPI & 0,95 & 1,00 & 0,83 & 1.12 \\
\hline Sewatama & 1.28 & 1,21 & 1.00 & 1.15 \\
\hline PYM & 0,88 & 0,89 & 0,87 & 1,00 \\
\hline$\Sigma$ Kolom & 4,12 & 4,15 & 3,48 & 4,40 \\
\hline
\end{tabular}

Sumber Data : Kuisioner dengan DM Pembangkitan PLN MMU

Perbandingan antar Alternatif Sub Kriteria Tingkat Kebisingan

Tingkat Kebisingan
\begin{tabular}{|l|r|r|r|r|}
\hline \multicolumn{1}{|c|}{ Kriteria } & Wesa & CPI & Sewatama & PYM \\
\hline Wesa & 1,00 & 0,33 & 3,00 & 0,50 \\
\hline CPI & 3,00 & 1,00 & 4,00 & 1,00 \\
\hline Sewatama & 0,33 & 0,25 & 1,00 & 0,33 \\
\hline PYM & 2,00 & 1,00 & 3,00 & 1,00 \\
\hline E Kolom & 6,33 & 2,58 & 11,00 & 2,83 \\
\hline
\end{tabular}

Sumber Data : Kuisioner dengan DM Pembangkitan PLN MMU 
Perbandingan antar Alternatif Sub Kriteria Biaya Pokok produksi

Biaya Pokok Produksi/KWH
\begin{tabular}{|l|r|r|r|r|}
\hline \multicolumn{1}{|c|}{ Kriteria } & Wesa & CPI & Sewatama & PYM \\
\hline Wesa & 1,00 & 1,32 & 0,93 & 1,10 \\
\hline CPI & 0,76 & 1,00 & 0,62 & 0,79 \\
\hline Sewatama & 1,07 & 1,62 & 1,00 & 1,15 \\
\hline PYM & 0,91 & 1,27 & 0,87 & 1,00 \\
\hline$\Sigma$ Kolom & 3,74 & 5,21 & 3,42 & 4,04 \\
\hline
\end{tabular}

Sumber Data : Kuisioner dengan DM Pembangkitan PLN MMU

Perbandingan antar Alternatif Sub Kriteria Harga Sewa

Harga Sewa
\begin{tabular}{|l|r|r|r|r|}
\hline \multicolumn{1}{|c|}{ Kriteria } & \multicolumn{1}{l|}{ Wesa } & CPI & Sewatama & \multicolumn{1}{l|}{ PYM } \\
\hline Wesa & 1,00 & 0,50 & 3,00 & 1,10 \\
\hline CPI & 2,00 & 1,00 & 2,00 & 3,00 \\
\hline Sewatama & 0,33 & 0,50 & 1,00 & 0,50 \\
\hline PYM & 0,91 & 0,33 & 2,00 & 1,00 \\
\hline$\Sigma$ Kolom & 4,24 & 2,33 & 8,00 & 5,60 \\
\hline
\end{tabular}

Sumber Data : Kuisioner dengan DM Pembangkitan PLN MMU

\section{Perhitungan Software (Excpert Choice 2000) Metode AHP}

Data dari kuisioner selain dilakukan perhitungan secara manual menggunakan program excel juga dihitung dengan aplikasi Expert Choice dengan tahapan sebagai berikut :

A. Perbandingan Antar Kriteria

Pada tingkat kedua, perbandingan berpasangan antara kriteria yaitu Aspek Teknis, Aspek Lingkungan dan Sosial, dan Aspek Biaya. Berikut ini merupakan hasil nilai rata-rata geometrik yang akan diolah.

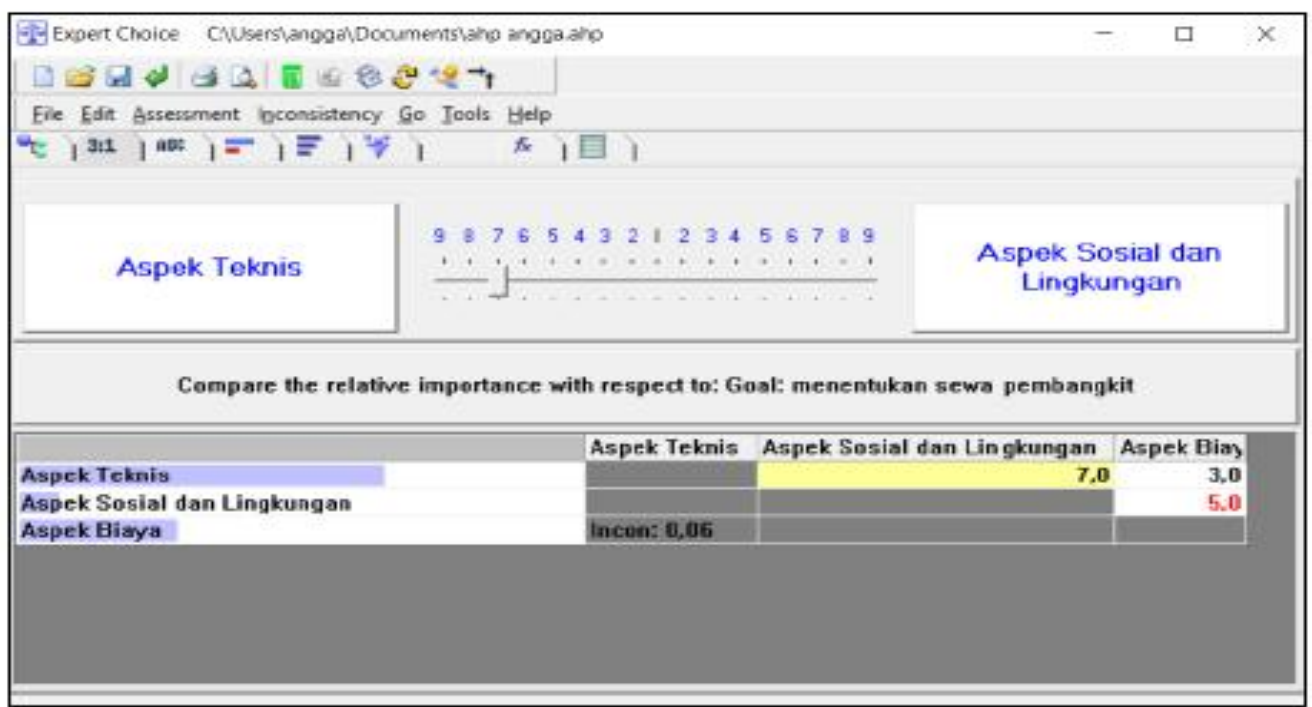

Nilai Perbandingan Berpasangan Antar Kriteria 


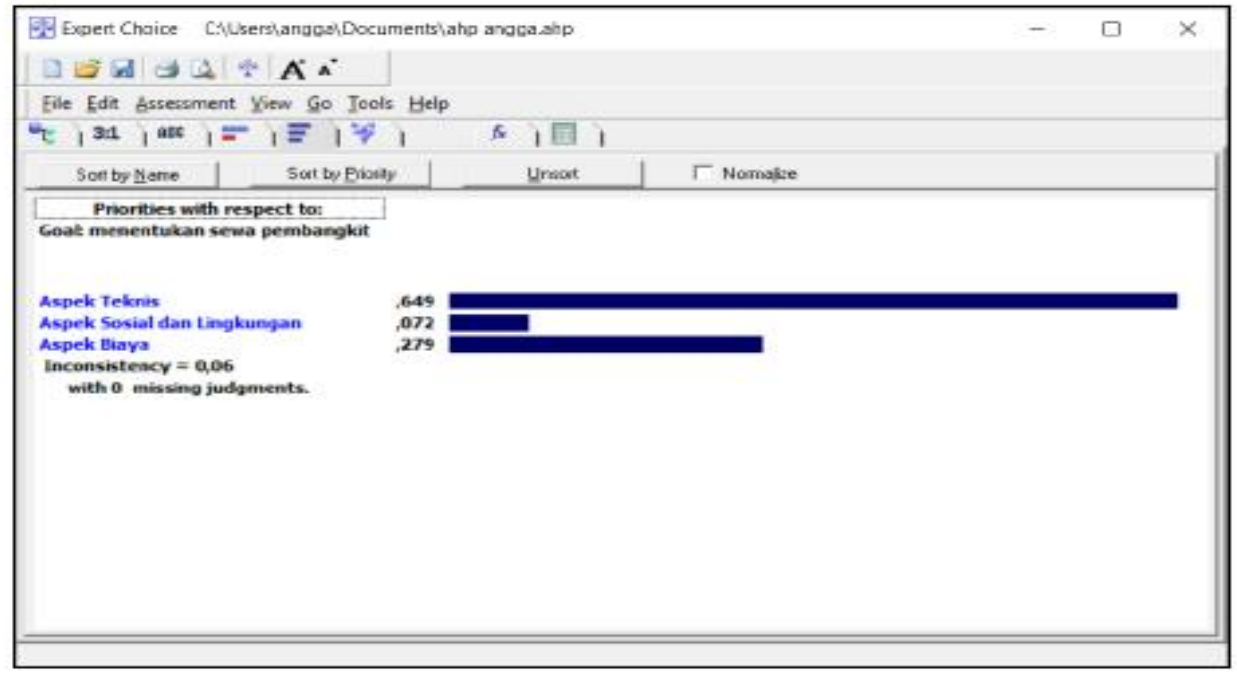

Hasil Perbandingan Berpasangan Antar Kriteria

Dari gambar diatas dapat dilihat bahwa bobot prosentase untuk Aspek Teknis yang paling besar yaitu 64,9\%, selanjutnya adalah Aspek Biaya dengan prosentase 27,9\%, dan yang terakhir adalah Aspek Lingkungan dan Sosial dengan prosentase 7,2\%.

B. Perbandingan Antar Sub Kriteria

Pada tingkat ketiga, adalah perbandingan berpasangan antara Sub kriteria dimana hasil running perbandingan antar sub kriteria menggunakan aplikasi Expert Choice adalah sebagai berikut :

1. Tingkat konsumsi bahan bakar dan waktu penyediaan daya kontrak (Aspek Teknis)

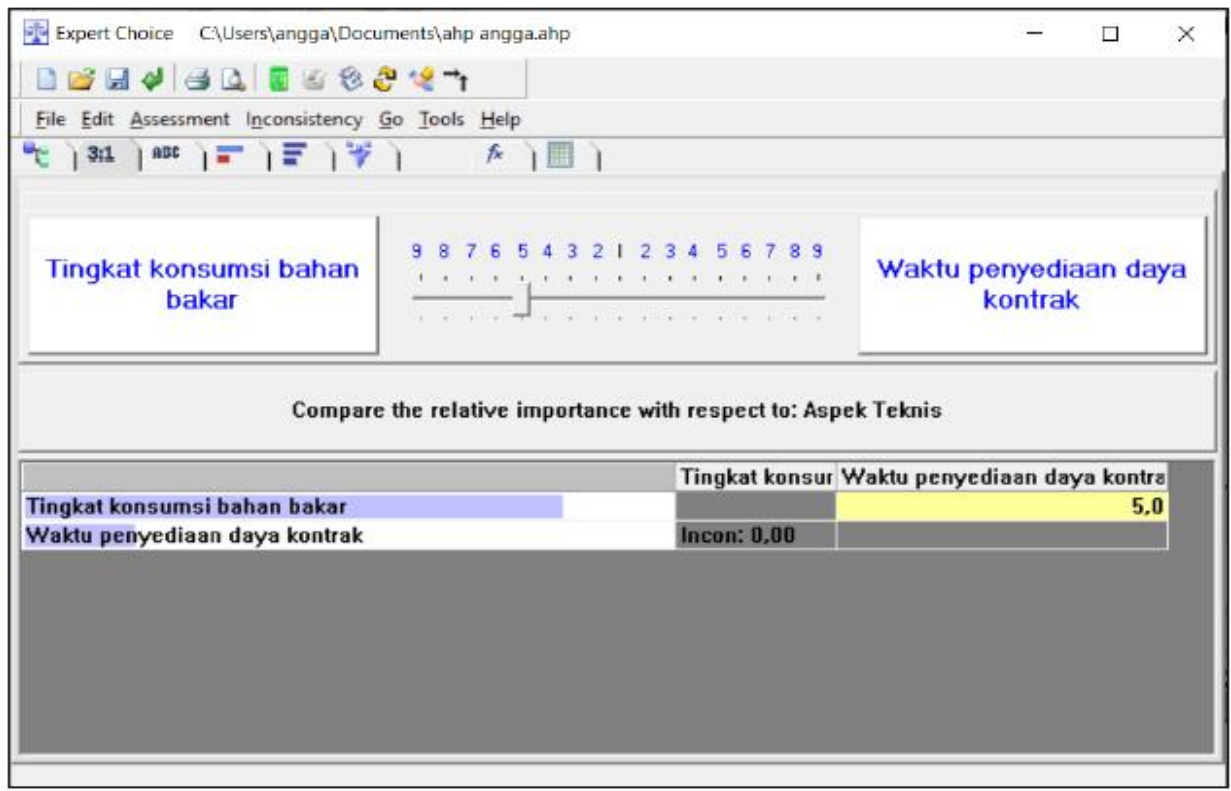

Nilai Perbandingan Berpasangan Antar Sub Kriteria pada Aspek Teknis 


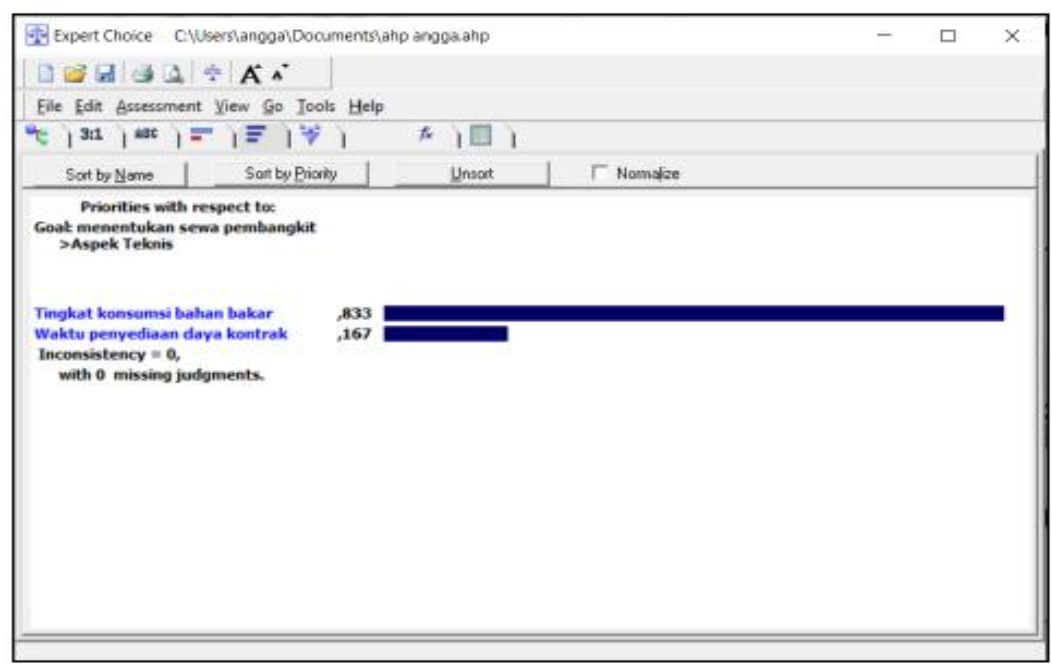

Hasil Perbandingan Berpasangan Antar Sub Kriteria pada Aspek Teknis

Dari gambar diatas menunjukan bahwa sub kriteria tingkat konsumsi bahan bakar mempunyai tingkat kepentingan yang paling tinggi dengan nilai 0,833 atau $83,3 \%$. Sub kriteria waktu penyediaan daya kontrak mempunyai nilai 0,167 atau $16,7 \%$.

2. Sub kriteria emisi gas buang dan tingkat kebisingan (Aspek Lingkungan dan Sosial)

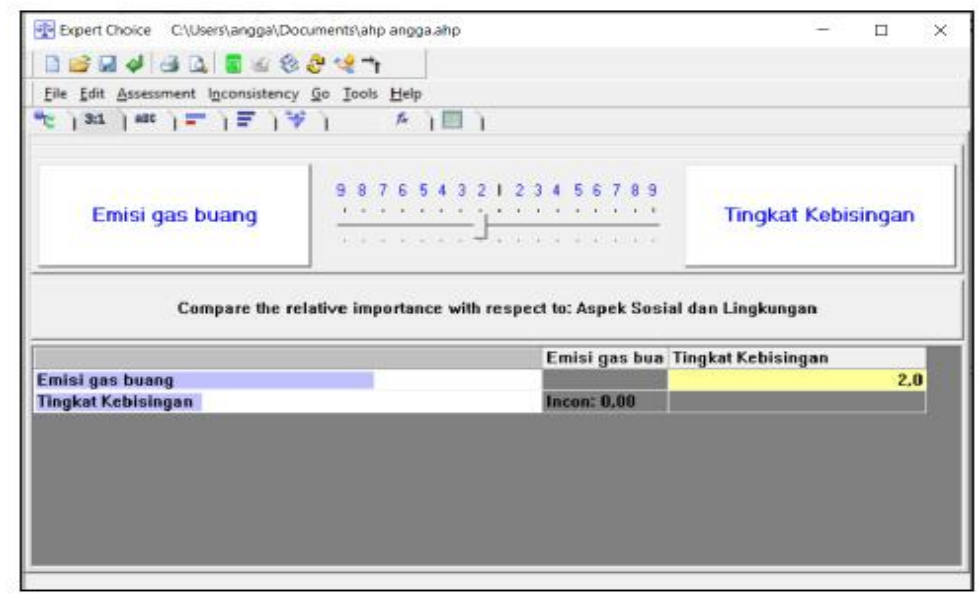

Nilai Perbandingan Berpasangan Antar Sub Kriteria pada Aspek Lingkungan dan Sosial

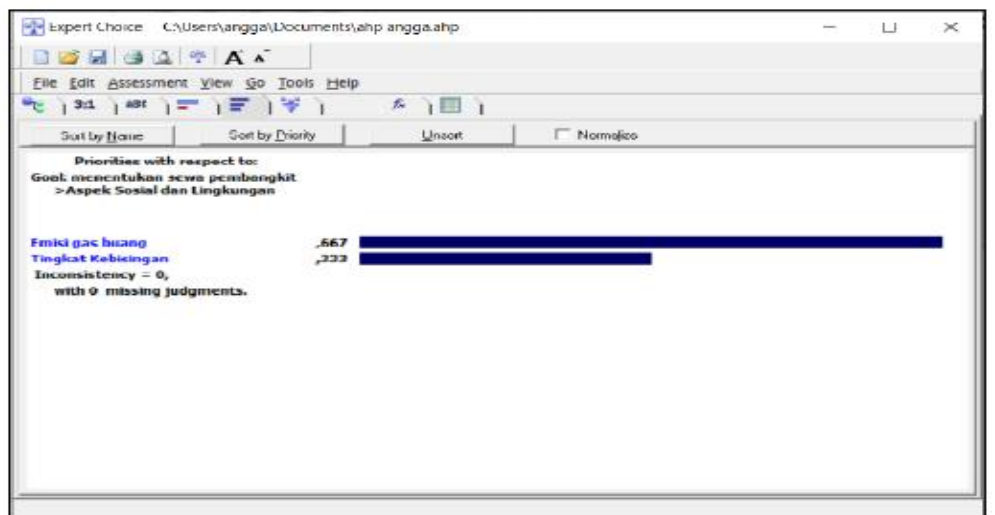

Hasil Perbandingan Berpasangan Antar Sub Kriteria pada Aspek Lingkungan dan Sosial 
Dari gambar diatas menunjukan bahwa sub kriteria emisi gas buang mempunyai tingkat kepentingan yang paling tinggi dengan nilai 0,667 atau $66.7 \%$. Sub kriteria tingkat kebisingan dengan nilai 0,333 atau 33.3 $\%$.

3. Sub kriteria Biaya Pokok produksi dan Harga Sewa (Aspek Biaya)

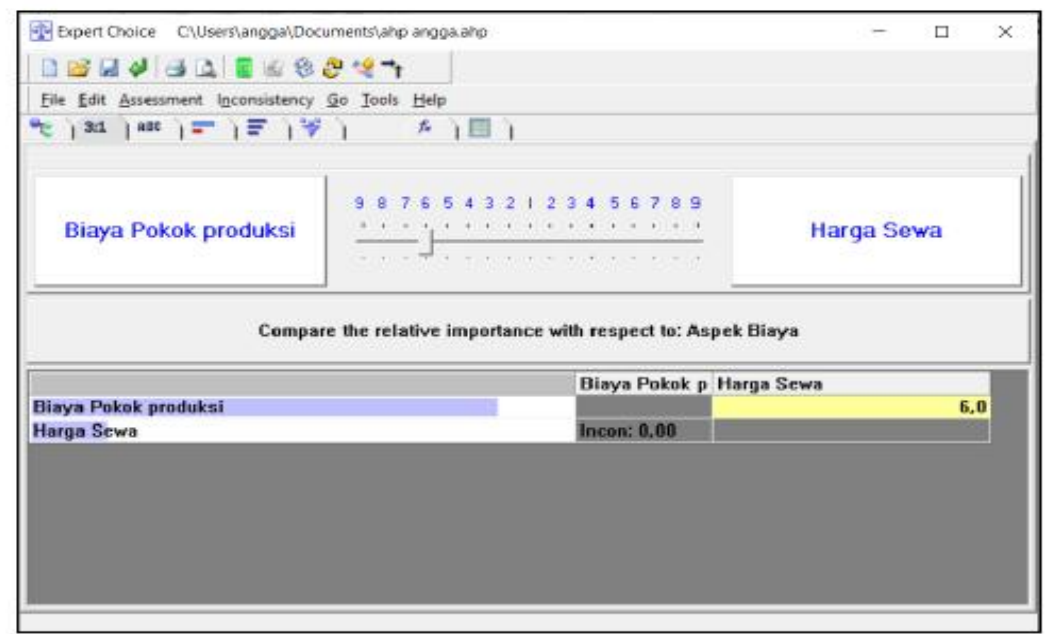

Nilai Perbandingan Berpasangan Antar Sub Kriteria pada Aspek Biaya

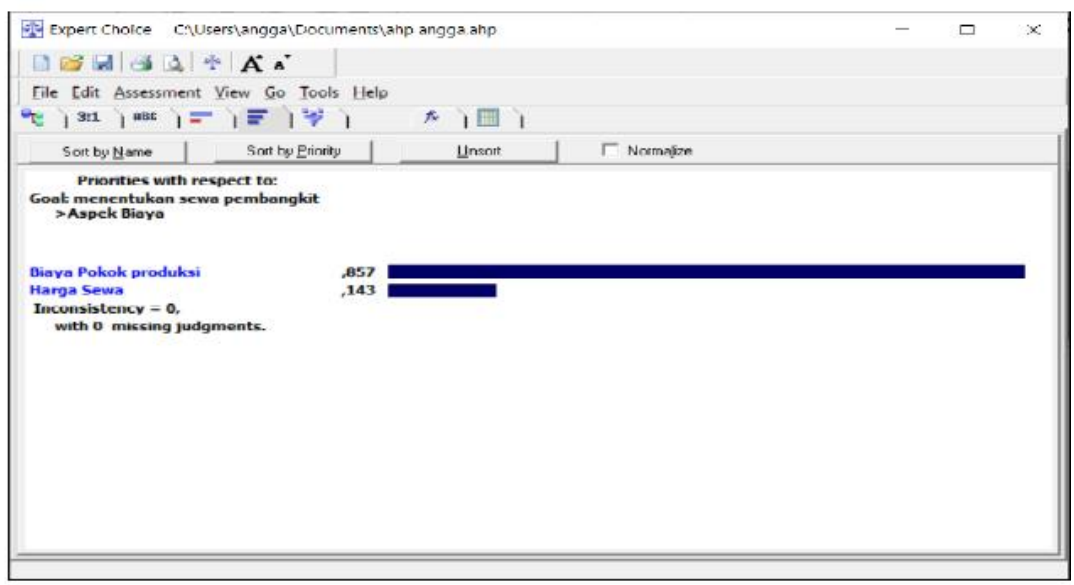

Hasil Perbandingan Berpasangan Antar Sub Kriteria pada Aspek Biaya

Dari gambar diatas menunjukan bahwa sub kriteria biaya pokok produksi mempunyai tingkat kepentingan yang paling tinggi dengan nilai 0,857 atau $85.7 \%$. Sub kriteria tingkat kebisingan dengan nilai 0,143 atau $14.3 \%$.

C. Perbandingan Sub Kriteria dengan Alternatif

Pada tingkat keempat, adalah perbandingan berpasangan antara Sub kriteria dengan alternatif. Keempat jenis pembangkit sewa dilakukan perbandingan terhadap masing-masing sub kriteria. Adapun hasilnya sebagai berikut :

1. Sub kriteria tingkat konsumsi bahan bakar dibandingkan dengan Alternatif Sewatama, Wesa, CPI dan PYM 


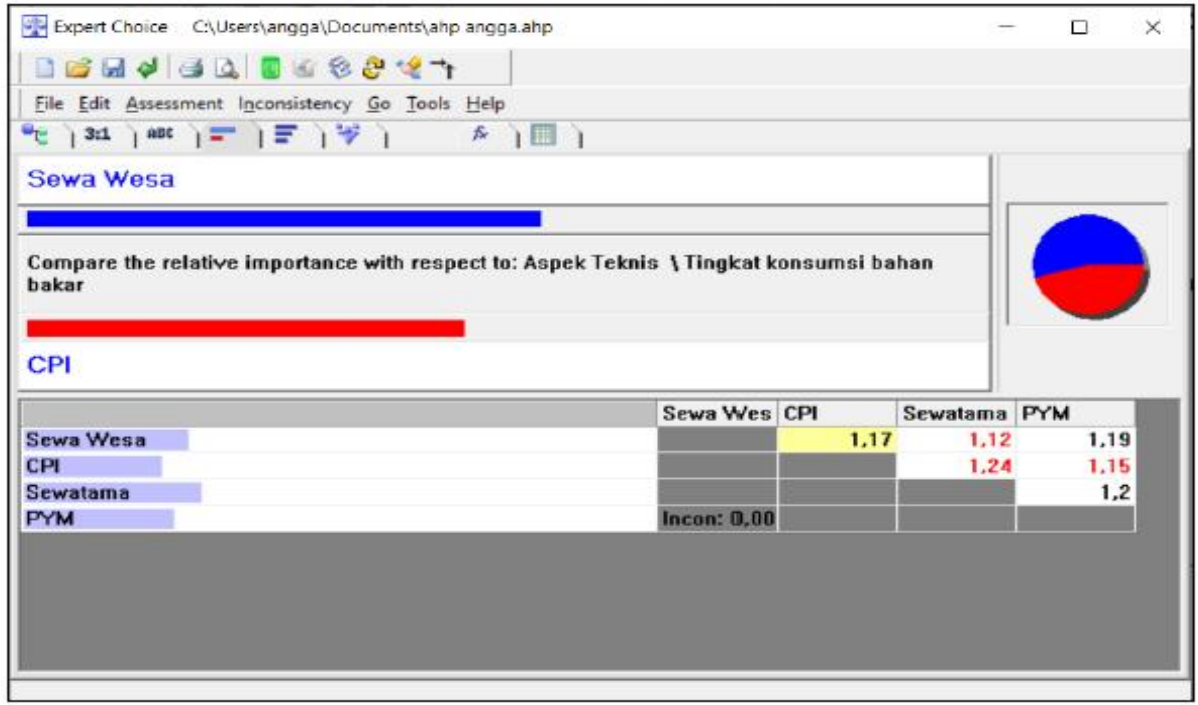

Nilai Perbandingan Berpasangan Antar Sub Kriteria tingkat konsumsi bahan bakar dengan Alternatif Pembangkit Sewa.

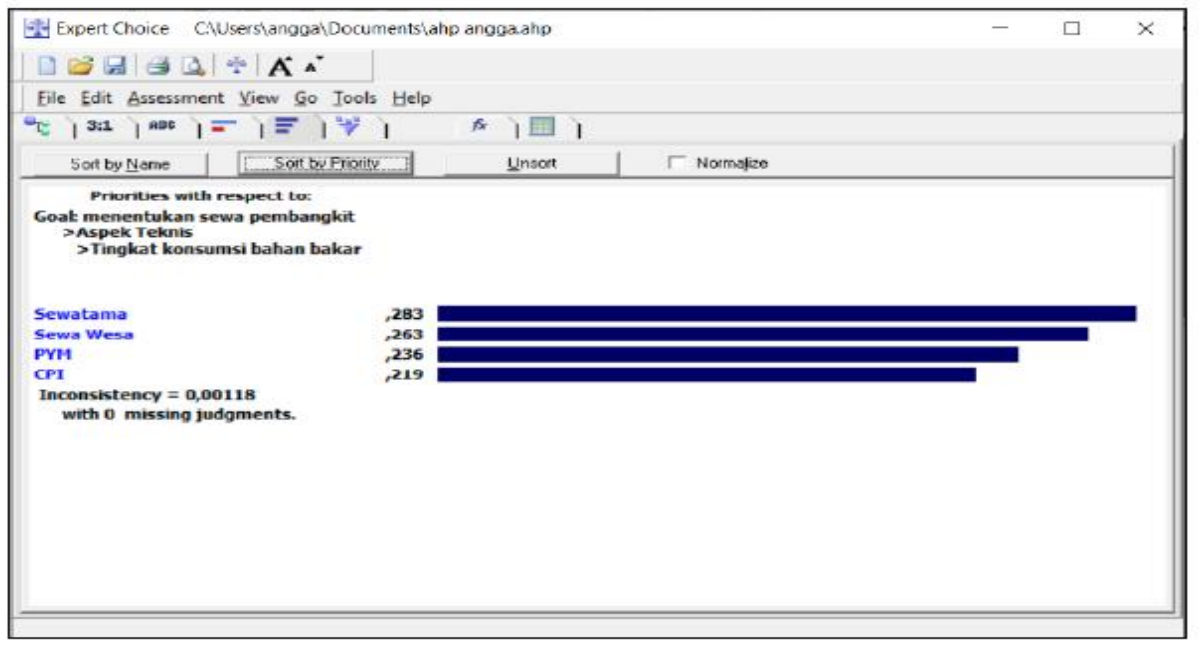

Hasil Perbandingan Berpasangan Antar Sub Kriteria tingkat konsumsi bahan bakar dengan Alternatif Pembangkit Sewa.

Hasil perbandingan berpasangan antar tingkat konsumsi bahan bakar dengan alternatif pembangkit Sewatama mempunyai nilai kepentingan atau bobot paling tinggi yaitu 0,283 atau 28,3\%, sedangkan Sewa wesa ada diurutan ke dua dengan nilai 0,268 atau 26,8\%, PYM dengan nilai 0,236 atau 23,6\% dan terakhir adalah CPI dengan nilai 0,219 atau $21,9 \%$.

2. Sub kriteria waktu penyediaan daya kontrak dibandingkan dengan Alternatif Sewatama, Wesa, CPI dan PYM 


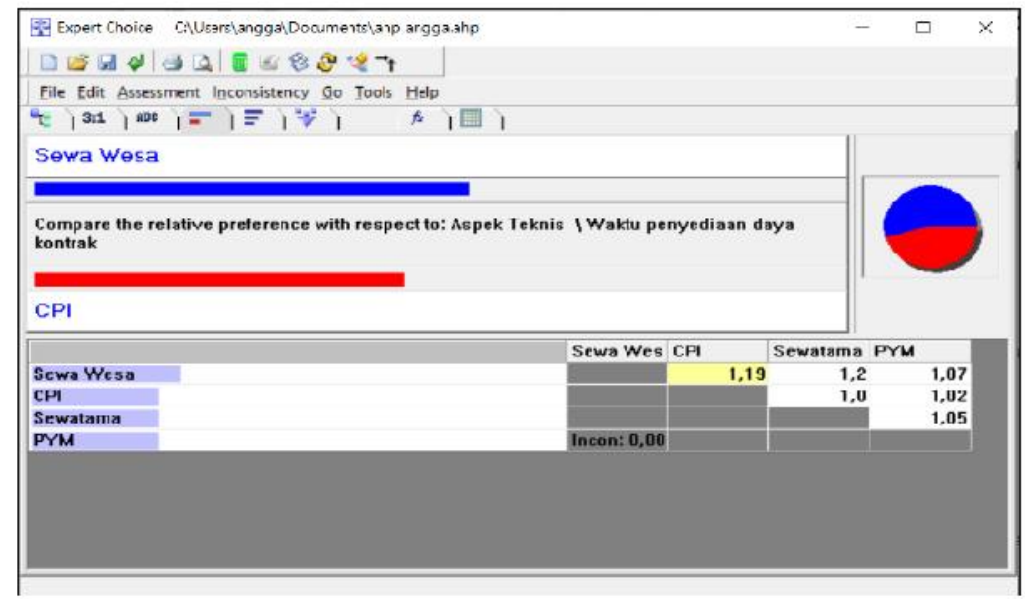

Nilai Perbandingan Berpasangan Antar Sub Kriteria waktu penyediaan daya kontrak dengan Alternatif Pembangkit Sewa

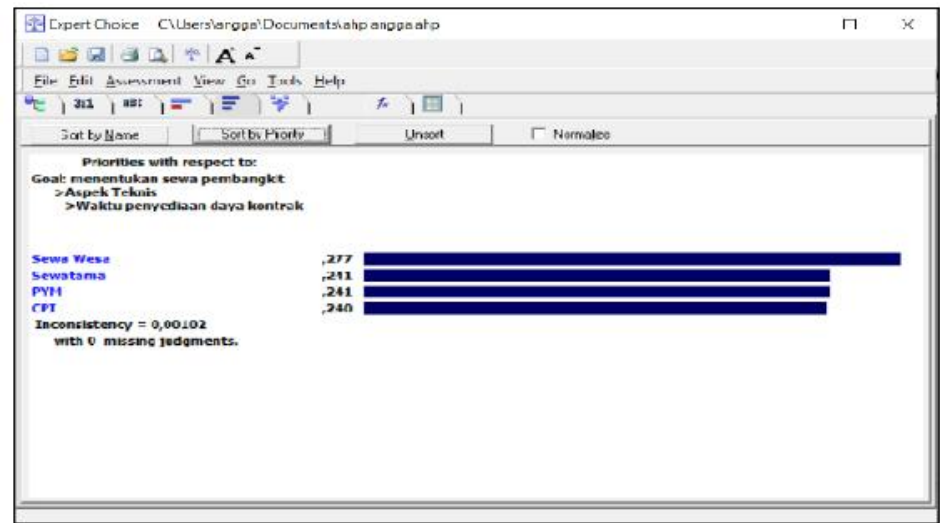

Hasil Perbandingan Berpasangan Antar Sub Kriteria waktu penyediaan daya kontrak dengan Alternatif Pembangkit Sewa.

Hasil perbandingan berpasangan antar waktu penyediaan daya kontrak dengan alternatif pembangkit Sewa wesa mempunyai nilai kepentingan atau bobot paling tinggi yaitu 0,277 atau 27,7\%, sedangkan Sewatama dan PYM ada diurutan ke dua dengan nilai sama yaitu 0,241 atau $24,1 \%$, dan terakhir adalah CPI dengan nilai 0,240 atau $24 \%$.

3. Sub kriteria Emisi Gas Buang dibandingkan dengan Alternatif Sewatama, Wesa, CPI dan PYM.

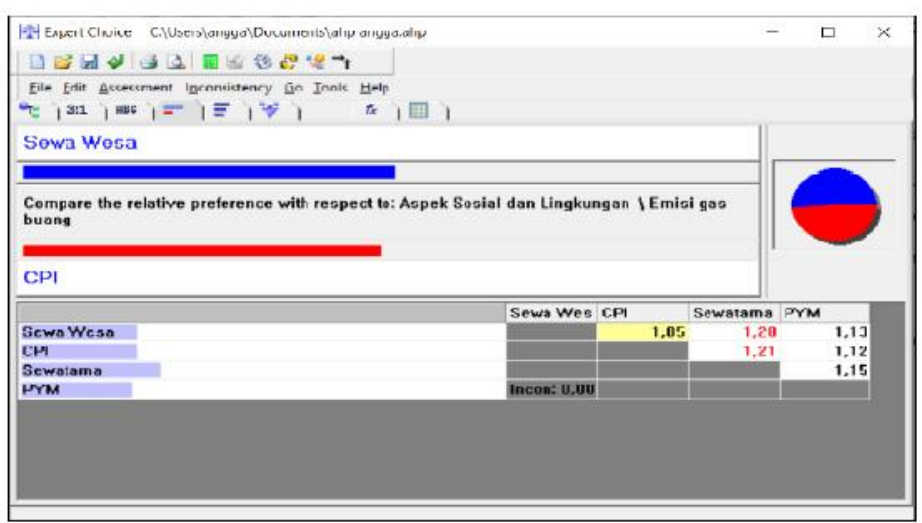

Nilai Perbandingan Berpasangan Antar Sub Kriteria Emisi Gas Buang dengan Alternatif Pembangkit Sewa. 


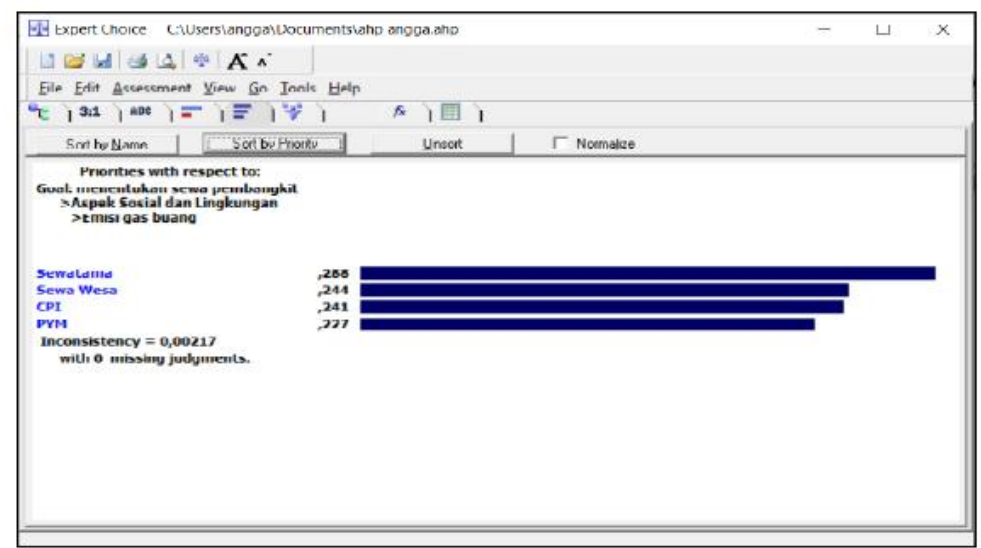

Hasil Perbandingan Berpasangan Antar Sub Kriteria Emisi Gas Buang dengan Alternatif Pembangkit Sewa.

Hasil perbandingan berpasangan antar Emisi Gas Buang dengan alternatif pembangkit Sewatama mempunyai nilai kepentingan atau bobot paling tinggi yaitu 0,288 atau 28,8\%, sedangkan Sewa Wesa 0,244 atau 24,4\% kemudian CPI dengan nilai 0,241 atau 24,1\%, dan terakhir adalah PYM dengan nilai 0,227 atau $22,7 \%$.

4. Sub kriteria Tingkat kebisingan dibandingkan dengan Alternatif Sewatama, Wesa, CPI dan PYM

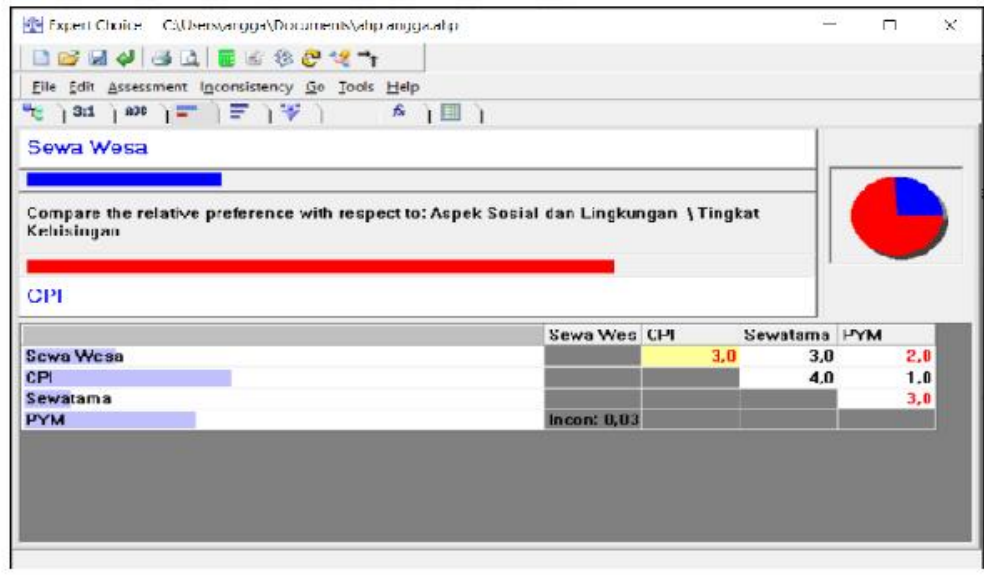

Nilai Perbandingan Berpasangan Antar Sub Kriteria Tingkat kebisingan dengan Alternatif Pembangkit Sewa.

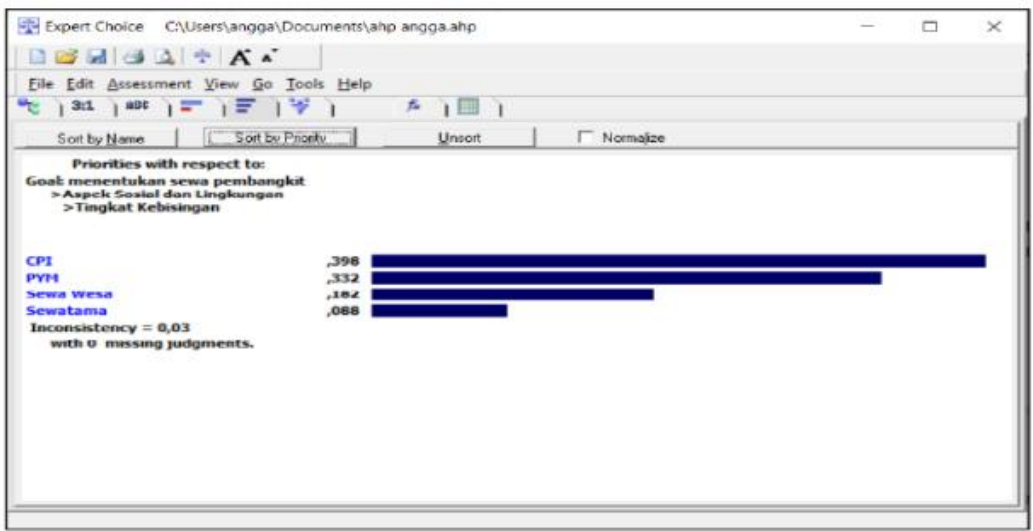

Hasil Perbandingan Berpasangan Antar Sub Kriteria Tingkat kebisingan dengan Alternatif Pembangkit Sewa. 
Hasil perbandingan berpasangan antar Tingkat kebisingan dengan alternatif pembangkit CPI mempunyai nilai kepentingan atau bobot paling tinggi yaitu 0,398 atau 39,8\%, sedangkan Sewa PYM 0,332 atau 33,2\% kemudian Sewa Wesa dengan nilai 0,182 atau 18,2\%, dan terakhir adalah Sewatama dengan nilai 0,088 atau $8,8 \%$.

5. Sub kriteria Biaya Pokok Produksi dibandingkan dengan Alternatif Sewatama, Wesa, CPI dan PYM

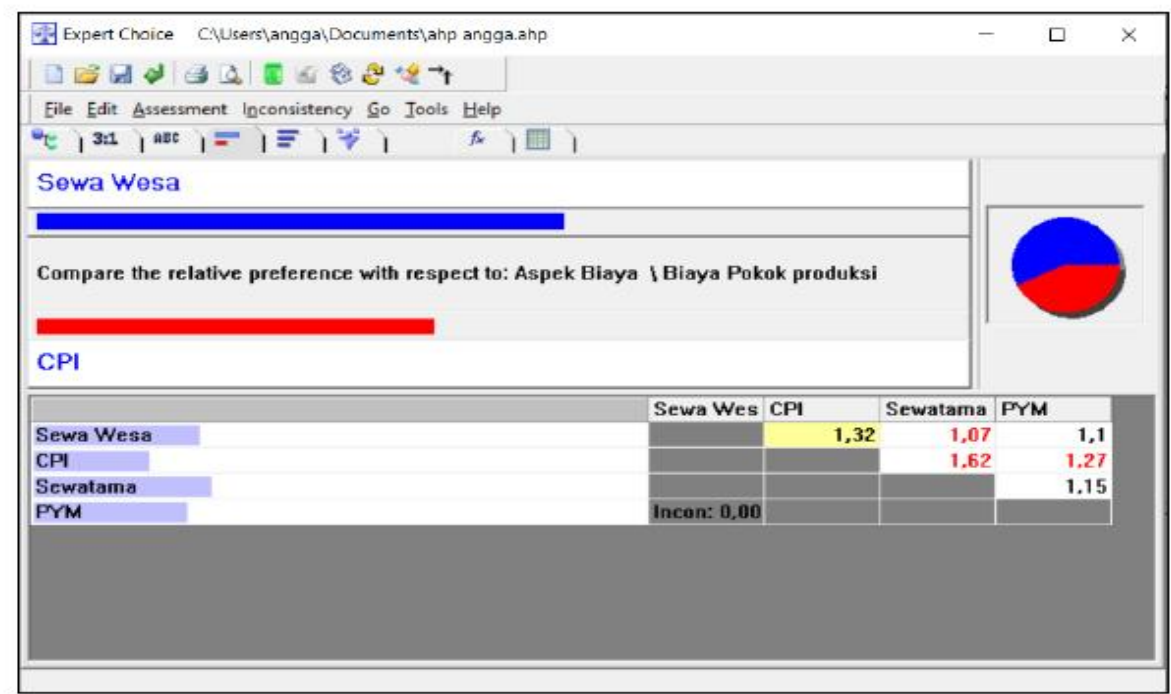

Nilai Perbandingan Berpasangan Antar Sub Kriteria Biaya Pokok Produksi dengan Alternatif Pembangkit Sewa

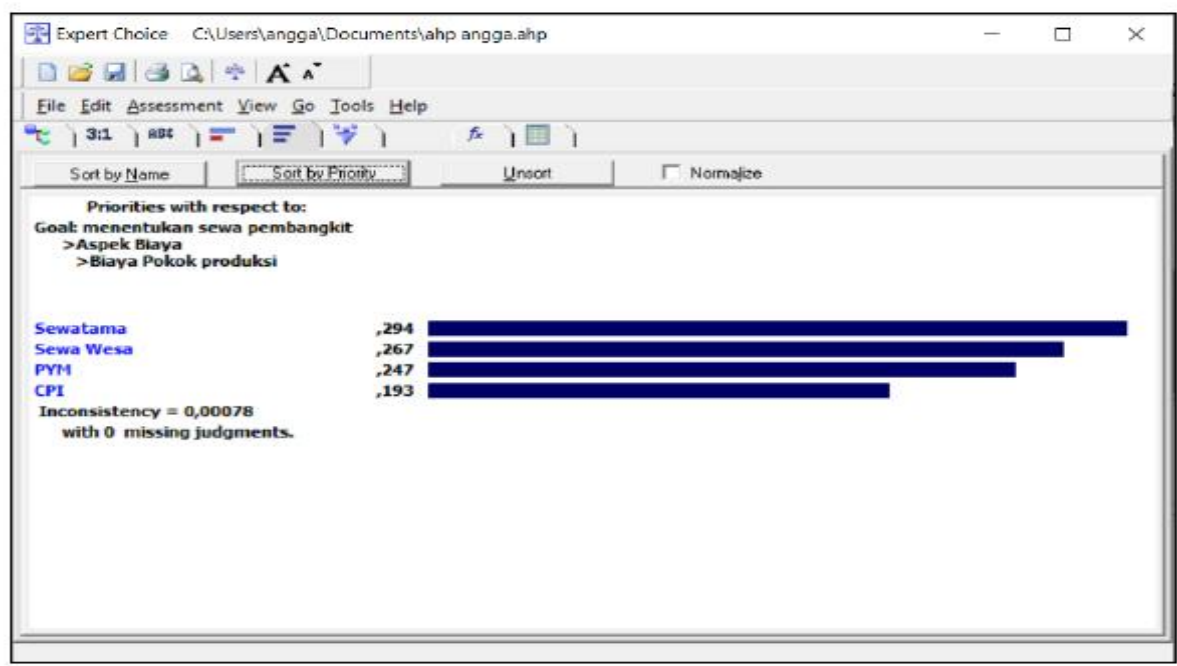

Hasil Perbandingan Berpasangan Antar Sub Kriteria Biaya Pokok Produksi dengan Alternatif Pembangkit Sewa

Hasil perbandingan berpasangan antar Biaya Pokok Produksi dengan alternatif pembangkit Sewatama mempunyai nilai kepentingan atau bobot paling tinggi yaitu 0,294 atau $29,4 \%$, sedangkan Sewa Wesa 0,267 atau 26,7\% kemudian Sewa PYM dengan nilai 0,247 atau 24,7\%, dan terakhir adalah Sewatama dengan nilai 0,193 atau $19,3 \%$. 


\section{Result / Hasil Akhir Running Aplikasi Expert Choice}

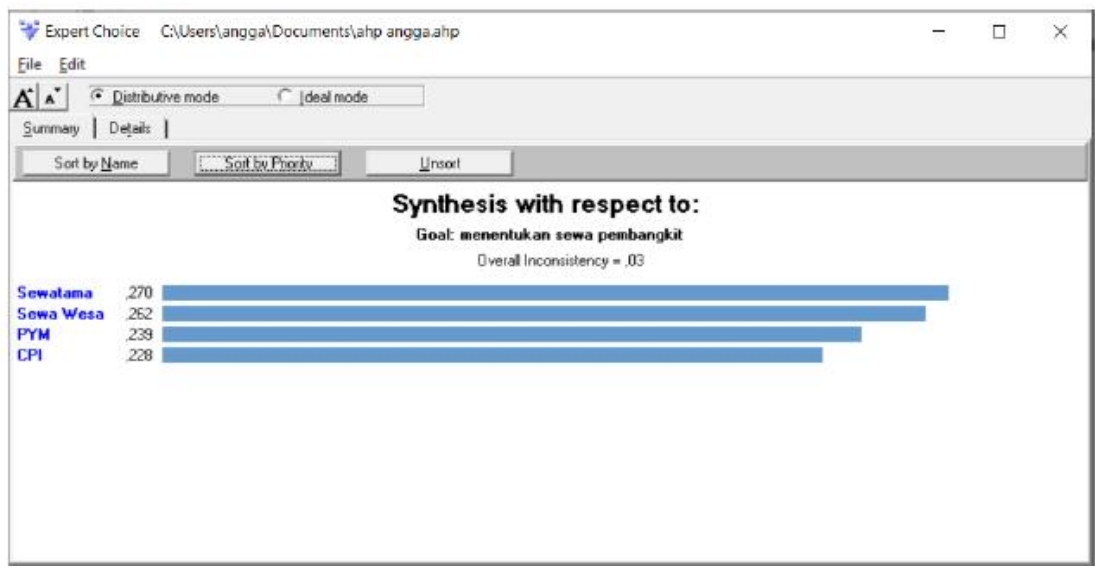

Result / Hasil Akhir Perbandingan Antar Kriteria, Sub Kriteria dan Alternatif.

Dari hasil running aplikasi Expert Choice pada gambar 4.28 disimpulkan bahwa alternatif pembangkit sewa yang paling optimal untuk dapat beroperasi di Sistem Ambon adalah Pembangkit Sewatama yang mana nilai kepentingan dari hasil running aplikasi tersebut adalah 0,270 atau bobot paling tinggi dengan prosentase $27 \%$, kemudian pada urutan kedua adalah pembangkit Sewa Wesa dengan nilai kepentingan 0,262 atau dengan prosentase 26,2 \%, kemudian pada urutan ketiga adalah pembangkit Sewa PYM dengan nilai kepentingan 0,239 atau dengan prosentase 23,9 \%dan alternatif yang terakhir adalah pembangkit Sewa CPI dengan nilai kepentingan 0,228 atau dengan prosentase paling kecil yaitu $22,8 \%$.

\section{KESIMPULAN}

Berdasarkan uraian-uraian dan analisa data yang dikemukakan pada bab sebelumnya yaitu tentang penggunaan metode AHP, maka dapat disimpulkan bahwa:

1. Kriteria - kriteria dalam penentuan pembangkit mesin sewa yang akan beroperasi di Sistem Ambon yaitu Aspek teknis yang terdiri dari sub kriteria Tingkat Konsumsi Bahan Bakar dan Waktu penyediaan daya kontrak. Kriteria Aspek Lingkungan dan Sosial yang termasuk sub kriteria didalamnya adalah emisi gas buang dan tingkat kebisingan. Selanjutnya kriteria Aspek Biaya yang terdiri dari biaya pokok produksi, biaya sewa

2. Pemilihan jenis pembangkit sewa yang digunakan sebagai alternatif keputusan adalah Sewatama, Sewa Wesa, Sewa CPI dan Sewa PYM

3. Hasil perhitungan AHP dengan menggunakan aplikasi Expert Choice adalah terpilihnya Sewatama sebagai pembangkit yang paling tepat di system ambon, karena mempunyai nilai kepentingan yang paling tinggi yaitu 0,270, sementara Sewa Wesa 0,262, Sewa PYM 0,239 dan Sewa CPI 0,228.

\section{DAFTAR PUSTAKA}

Badri, M. A. (2001). A Combined AHP - GP Model for Quality Control Systems.International Journal of Production Economics 72 , pp 27-40.

Expert Choice. (2004)., User Guide Version 11. Arlington VA USA : Expert Choice Inc.

Goodwin, P. \& Wright, G., (2004)., Decision Analysis for Management Judgment, Third Edition, John Wiley \& Sons Ltd., England.

Harker P. T., Vargas L. (1987)., The Theory Of Ratio Scale Estimation: Saaty's Analytic Hierarchy Proces. Journal of management science Vol.33 No.11. pp 1383-1403.

Ishizaka Alessio, Lusti Markus (1998)., How To Derive Priorities In AHP: A Comparative Study. Journal of the operations research Vol.41 No.3. pp 51-61.

Ispen. (1998)., Aplikasi “Analytical hierarchy Process” AHP Untuk Penentuan Prioritas Pembangunan. Semarang : FPTK IKIP Semarang.

Kou, Gang,. (2013). Data Processing for the AHP/ANP. Springer. London.

K. Tone (1986)., The Analytic Hierarchy Process: Decision Making . Japanese Science And Technology Press.

PLN Udiklat Suralaya, (2012)., Operasi dan Pemeliharaan PLTU, Suralaya 
PLN Udiklat Makassar, (2012), Operasi dan Pemeliharaan PLTD, Makassar

Saaty, Thomas L. (1988)., Fundamental of Decision Making and Priority Theory with the Analytic Hierarchy Process Vol. VI. RWS Publications. USA.

Shiraishi Shunsuke, Obata Tsuneshi , Daigo Motomasa (1998)., Properties Of A Positive Reciprocal Matrix And Their Application To AHP. Journal of the operations research Vol.41 No.3. 
